\title{
Assessment of Soil Quality for a Semi-Arid Irrigated Under Citrus Orchard : Case of the Haouz Plain, Morocco
}

\author{
Salma Sefiani, PhD \\ Abdennabi El Mandour, Dr \\ Nour-Eddine Laftouhi, Dr \\ Nourddine Khalil, Dr \\ Safia Kamal, PhD
}

University Cadi Ayyad. Faculty of Sciences Semlalia, Marrakesh, Morocco. Laboratory Géostructures, Geomaterials and water resources (GEOHYD), International joint laboratory: TREMA, URAC 44 Equipe associée au

CNRST

\section{Lionel Jarlan, Dr Abdelghani Chehbouni, Dr}

Research Institute for Development, Centre d'Etude Spatiales de la BIOsphère, Toulouse, France

\section{Lahoucine Hanich, Dr}

University Cadi Ayyad, Faculty of Sciences and Techniques, Marrakesh, International joint laboratory: TREMA, Laboratory Georessources

Said Khabba, Dr

University Cadi Ayyad. Facutly of Sciences Semlalia, Marrakesh, Morocco.

Laboratory of Molecular Modeling

And ecophysiological (LMME), International joint laboratory: TREMA

\section{Addi Hamaoui}

Managers Agafay Area

\begin{abstract}
The irrigated perimeter of the Haouz plain is one of the largest in Morocco with $310.000 \mathrm{Ha}$ with intense agricultural practices based on irrigation. Besides, recent studies have shown that the aquifer is characterized by an overall average to low sensitivity and vulnerability. The objective of this study is to provide an in depth diagnosis of the current situation regarding soil quality for a drip irrigation area: a citrus orchard, in a farm named Agafay, is located in the western part of Haouz, at $35 \mathrm{~km} \mathrm{SW}$ of Marrakesh. To this
\end{abstract}


objective, an intensive in situ campaign has been carried out focused on the measurements of the physico-chemical parameters of soil, at nine plots. The variation of these parameters, their impact on the type of rootstock and the variation of pollutants through the five soil horizons are analyzed.

The results revealed that the condition in the soil quality is not very alarming. As most of the soils are light-textured, with poor organic matter content and basic to very basic $\mathrm{pH}$. The reduction of organic matter, salinity, orthophosphates and nitrates with depth is attributed to the localized mode of irrigation adopted at the site which minimizes the loss of nutrients and, in fine, pollution of the aquifer. Multivariate analysis shows that the total and lime correlate well with the $\mathrm{pH}$, which in turn correlate negatively with nitrate content and soil electrical conductivity.

This work has strong implications for the quality assessment of soil for all irrigated perimeters by the drip in semi-arid areas, order to ensure the conservation and sustainability of the production system.

Keywords: Agricultural intensification, Irrigated area, Physico-chemical quality of soil

\section{Introduction}

In Morocco, water resources are facing both quantity and quality problems that threaten agricultural development, while it is an important part of the national economy. Agricultural intensification is well known to have a positive effect on the yields. However, it is usually associated with the deterioration of the quality of the soils (Mathieu et al, 1980; Larson et al, 1991; Umali, 1993; Farhat, 1995; Robert, 1992; Badraoui, 1998), and of the groundwater related to salinity problems, sodification, and nitrate pollution (Rahoui et al, 1999; Fetouani et al, 2008; Bendra, 2012).

Several studies have been carried out to evaluate the quality of soils in irrigated areas namely for the Tadla region (Berdai et al, 2004), for Doukalla (Rahoui et al, 2002), for Marrakech N'Fis (Sbai et al, 2006) and for Triffa (Fetouani et al, 2013), shows that intensive agriculture in irrigated areas is responsible for diffuse pollution mainly attributed to a misuse of agrochemical inputs and a lack of irrigation control and drainage. Consequently, salinization phenomena, sodification, deterioration of soil structure, and nitrate pollution of groundwater is taking an increasing rate in Morocco.

The objective of this work is the analysis of physico-chemical parameters and variations of these parameters through the different soil horizons, and under different rootstocks and assess the pollution (or not) of soil, focusing mainly nitrates and their fate in the soil beyond the root zone at an irrigated area by the drip, so we are faced with an ideal case where the 
agricultural practice are mastered and are under the supervision permanant a qualified agronomists team.

\section{Geographical setting, geology and hydrogeology}

The western Haouz is a part of the Haouz plain, it is a depression extending over an area of $2800 \mathrm{~km}^{2}$ located thirty kilometers west wards from the city of Marrakesh. It is bounded to the north by the Jebilets mountain range, to the south by the Western High Atlas Massif, to the east by the Wadi N'fis and to the west by the Bou Sbaa plateau. It is characterized by moderate relief (average elevation is $600 \mathrm{~m}$ ) which becomes more pronounced towards the south near the Atlas chain. It is in the form of a succession of anticlinal ridges East - West direction to North East-South West, separated by flatbottomed synclines (Ambroggi et al, 1952).

The plain of Haouz is considered a sedimentation basin in which accumulated tertiary and quaternary formations essentially clastic continental made by surface runoff of Atlasic chain (ABHT, 1987). The structuring of Western Haouz is in the form of two separate bowls by outcrops of Koudiat Moukhaden, the most important is Mejjate oriented east-west filled by secondary and tertiary deposits. Then Sid Zouine is elongated between wadi N'fis and Koudiat Moukhaden to the west.

Two types of reservoir hydrogeological interest are in this western part of the plain of Haouz. The unconfined aquifer corresponds to the northern part between the Marrakech-Chichaoua road and the Jebilet Hills intensively exploited for irrigation. The upper aquifer is found over the entire Western Haouz plain, although little is known about its structure (Chouikri et al, 2014). It is composed by two layers, mio-pliocene conglomerates of low transmissivity $\left(6.10^{-5} \mathrm{~m}^{2} / \mathrm{s}\right)$ covered by quaternary alluvium of higher transmissivity $\left(3.10^{-2} \mathrm{~m}^{2} / \mathrm{s}\right.$ to $\left.4.10^{-3} \mathrm{~m}^{2} / \mathrm{s}\right)$. The deep confined aquifer shows the highest transmissivity $\left(2.10^{-2} \mathrm{~m}^{2} / \mathrm{s}\right)$ and consists in dolomitic limestones of cenomano-turonian and Eocene age. Up to date, this very productive and very localized aquifer was only found in the southern area of the Western Haouz plain, named Mejjate plain.

\section{Study site}

The studied area is a farm named "Agafay" located about $35 \mathrm{~km}$ southwest of Marrakech city. The irrigated perimeter is situated in Agafay village between ( $8^{\circ} 15^{\prime} 17,37^{\prime \prime} \mathrm{N}$ longitude $31^{\circ} 29^{\prime} 50,19^{\prime \prime} \mathrm{S}$ latitude).

The study site is equipped with drip irrigation system and covers a total area of 1610 hectares. The irrigated area is 430 ha and is mainly covered by Clementine orange (variety: Afourar) and olive trees (varieties: P Moroccan, Longuedoc, Dahbia, Ascolana) (Fig. 1). Irrigation water comes from two 
sources: the dam Takerkoust and Agafay on one hand, and groundwater on the other hand.

The climate is semi arid with a very variable rainfall from year to another. The average annual rainfall is around $250 \mathrm{~mm}$ and the potential Evapotranspiration is $1600 \mathrm{~mm}$ / year according to the FAO Penman Monteith equation.

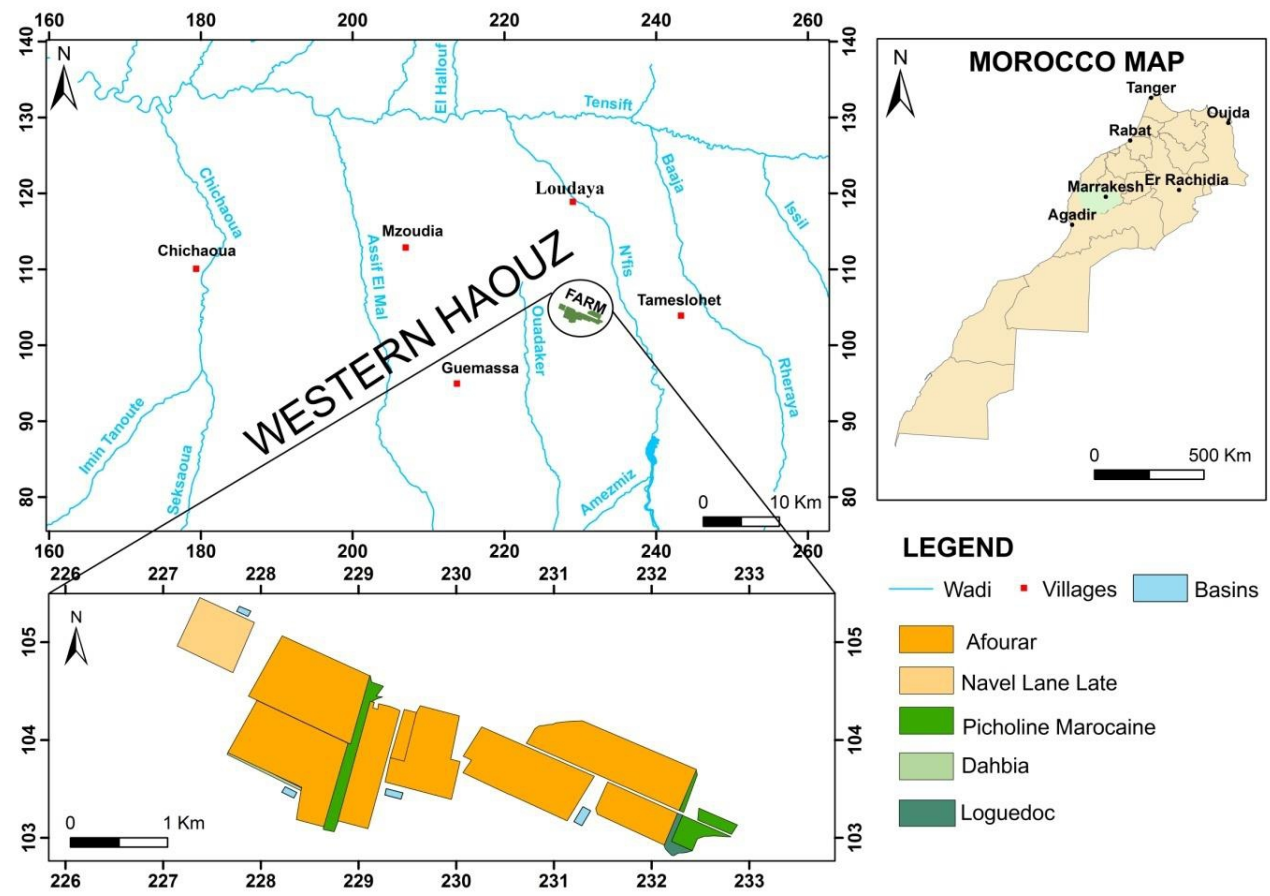

Fig. 1. Geographical location of the studied farm AGAFAY.

\section{Materials and methods}

\section{Sampling protocol and soil analysis}

Seventy three samples locations were taken from the top layer of soil $(0-30 \mathrm{~cm})$ in February 2014. The sampling points were distributed all over the study farm to ensure appropriate spatial coverage of the entire agricultural area. The sampling method is on zig-zag along the diagonal of a plot. (fig.2.A) In addition, fifteen sites were selected to study the vertical profiles under different rootstocks at a test plot (plot 7), (Fig.2B). The sampling concerned the following five horizons: $0-20 \mathrm{~cm}, 20-40 \mathrm{~cm}, 40-60 \mathrm{~cm}, 60-80 \mathrm{~cm}$ and $80-$ $100 \mathrm{~cm}$. 


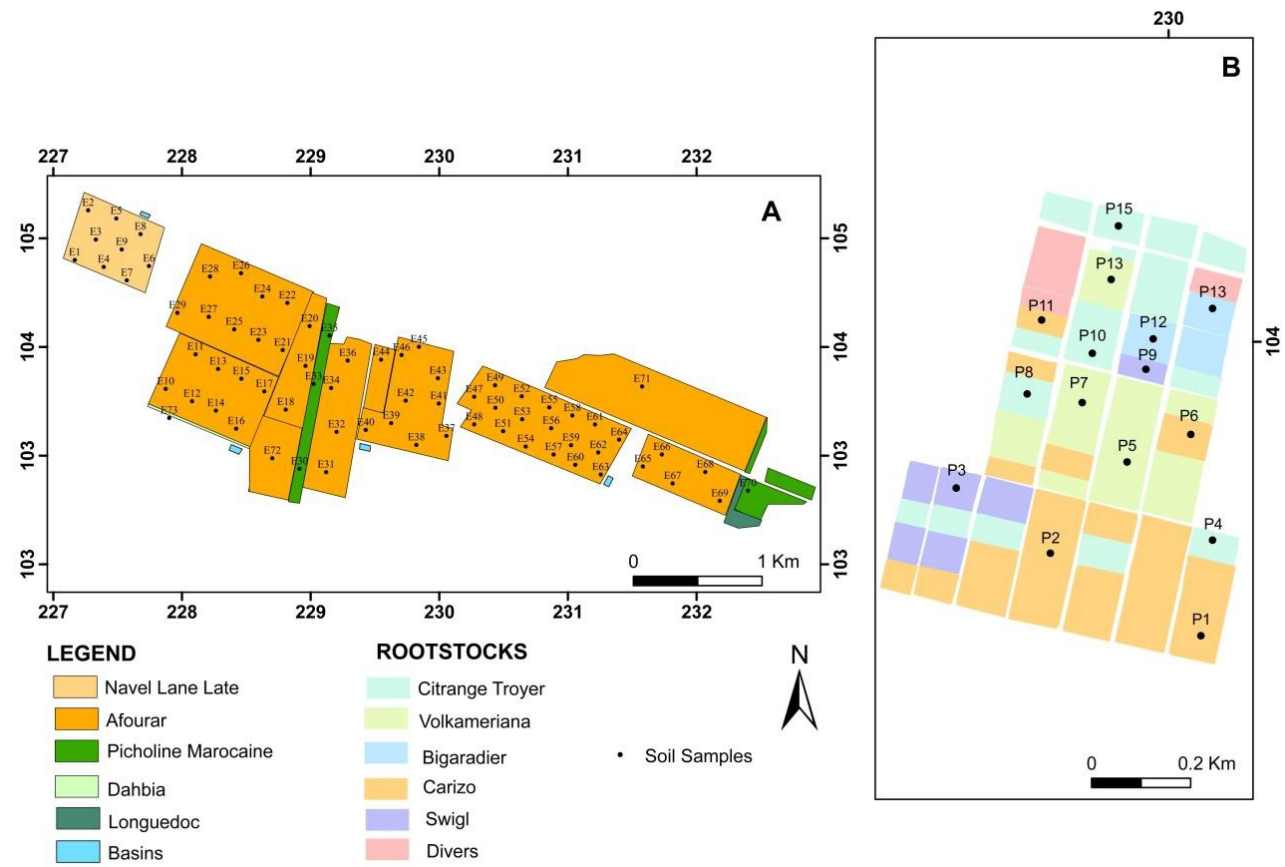

Fig. 2. Soil sample locations within the studied farm

A: sampling of surface layer $(0-30 \mathrm{~cm}) ; \quad$ B: sampling of vertical profiles.

The samples were air-dried and sieved to $2 \mathrm{~mm}$ diameter. The sieved fraction was then stored in plastic boxes at room temperature before analysis. The quality parameters that are monitored are: salinization, sodification, nitrate pollution. They have been selected on the basis of probable risks of soil degradation due to the practice on the site.

The interpretation of the results is performed either based on predetermined standards; if local or international (FAO, 2003; EPA, 1994; AFNOR - ISO, 1992). It is very useful to make the comparison of monitoring results with the reference areas (not affected by soil degradation processes) to determine the evolution and changes that have affected the quality of the soil after irrigation and intensive development.

Finally, the physico-chemical parameters are as follows:

- $\quad$ The particle size distribution was performed with the Robinson pipette method by sedimentation after dispersion with sodium pyrophosphate (Day, 1965)

- The Soil organic matter (SOM): It is estimated by the Walkley\& Black's method, by multiplying the percentage of organic carbon by a factor of 1,724 according to (Nelson et al, 1982) 
- $\quad$ The $\mathrm{pH}$ : it was measured in the soil solution (1:2.5) using a digital $\mathrm{pH}$ meter (WTW model 530, Lutron Electronic Co Inc., Coopersburg, Pennsylvania, USA).

The electrical conductivity: it is measured on a substrate-water extracted with a 1/5 ratio (mass-volume) after stirring for $30 \mathrm{~min}$.

- Available phosphorus: This method estimates the relative bioavailability of ortho-phosphate $\left(\mathrm{PO}_{4}-\mathrm{P}\right)$ in soils by extraction using alkaline sodium bicarbonate $(\mathrm{pH} 8,5)$ solution and determining the $\mathrm{P}$ concentration in the extract calorimetrically. (Olsen et al, 1954)

- The pourcentage calcium carbonate $\mathrm{CaCO}_{3}(\%)$ : its determination is based on the volumetric analysis of the carbon dioxide $\mathrm{CO}_{2}$, which is liberated during the application of hydrochloric acid solution $\mathrm{HCl} 4 \mathrm{~N}$ in soil's carbonates.

- $\quad$ Nitrates: it is measured on an extract of the saturated paste using the chromatography ionique.

The statistical analysis of data is performed using software XLSTAT 2015, to determine the main correlation factors and define the principal component analysis (PCA) between correlations between soil quality parameters.

\section{Results and Discussion}

\section{Spatial variability of the soil quality}

Soil texture is one of the most important physical properties of soils as it affects water retention nutrient availability, poor space, slope stability aeration and erosion susceptibility. The soil has a light texture loamy sand clay loam to sandy clay characterized by the dominance of the sand fraction $(53 \%)$, silt $(24 \%)$ and clay $(23 \%)$.

The value of the electrical conductivity varies from $574 \mu \mathrm{S} / \mathrm{cm}$ at 5500 $\mu \mathrm{S} / \mathrm{cm}$ with an average of about $2050 \mu \mathrm{S} / \mathrm{cm}$. These electrical conductivity values allow us to classify these soils in the class of saline soils (Mathieu et al, 2003).

The $\mathrm{pH}$ ranges between 8,1 to 8,78 . According to soil repository (AFES, 1992), the soil of the study site is usually basic to very basic. The soil alkalinity reduces availability of essential nutrients to plants (Bensaadi, 2004) and contributes frequently to the formation of insoluble hydroxides (Heller et al, 1998; FAO, 2003).

The organic material varies between $0,56 \%$ and $2,32 \%$.According to standards, soils are poor to very poor in organic matter. The organic matter is considered the main indicator of soil quality (Larson et al, 1991; Doran et al, 1994). Soil well supplied with organic matter will provide a more favorable environment for the development of crops and less sensitive to climate hazards. It plays a very important role in maintaining the structural stability of 
the soil, and in providing nutrients for crop growth (Baldock, 2000) from the floor.

The calcium carbonate is a component inherited from the ground. The presence of limestone in soil influences the biological activity. A shortage of limestone leads to progressive acidification depending on the soil and climate context which is necessary to compensate by regular intake of basic amendments. By comparing the values obtained with those reported by (Baize, 1988), we find that the floor of the study site is moderately limestone. The alkalinity of the soil is probably related to the nature of the parent rock that is of calcareous origin, the values of calcium carbonate range between $5.3 \%$ and $22 \%$.

Phosphorus is a minor element of the chemical composition of the soil, but it is considered indispensable to the growth and development of plants. Knowing the phosphorus content of the soil is essential for optimizing the agronomic and economic plan. The interpretation of the soil $\mathrm{P}_{2} \mathrm{O}_{5}$ contents depend on the extraction method used (Gagnard et al, 1988). In our case, we used the method (Joret, 1955) since the soil is moderately limestone. From the results obtained, the present ground of a globally strong Phosphoric acid contents in the superficial layers. The concentrations vary between $6 \%$ and $42 \%$ with an average grade of $16 \%$.

The spatial variation in nitrate concentrations extracted from the saturated paste varies between 0,05 and $177,2 \mathrm{mg} / 1$. The nitrate levels appear to be more concentrated for the variety of oranges "Navel Lane Late". It is essentially influenced by the contribution of nitrates fertilizers.

\section{Soil quality vertical evolution}

The study of the vertical soil quality is based on achieving fifteen vertical profiles under the following horizons: $0-20 \mathrm{~cm}, 20-40 \mathrm{~cm}, 40-60 \mathrm{~cm}$, $60-80 \mathrm{~cm}$ and $80-100 \mathrm{~cm}$. These profiles were chosen under different rootstocks in order to have an idea about the chemical elements variation, their impact on the type of rootstock and the variation of pollutants through the different soil horizons.

The analysis of different profiles to different rootstocks shows a reduction under different backgrounds of the organic matter content, electrical conductivity, orthophosphates, and nitrate except for $\mathrm{pH}$ and total limestone.

It clearly appears that the organic matter content decrease with depth in all rootstocks. The surface horizon is usually the place of accumulation of organic matter, they continuously receive vegetal refunds, while within depth horizons the influence of the fresh organic matter etompe (Fig.3). 


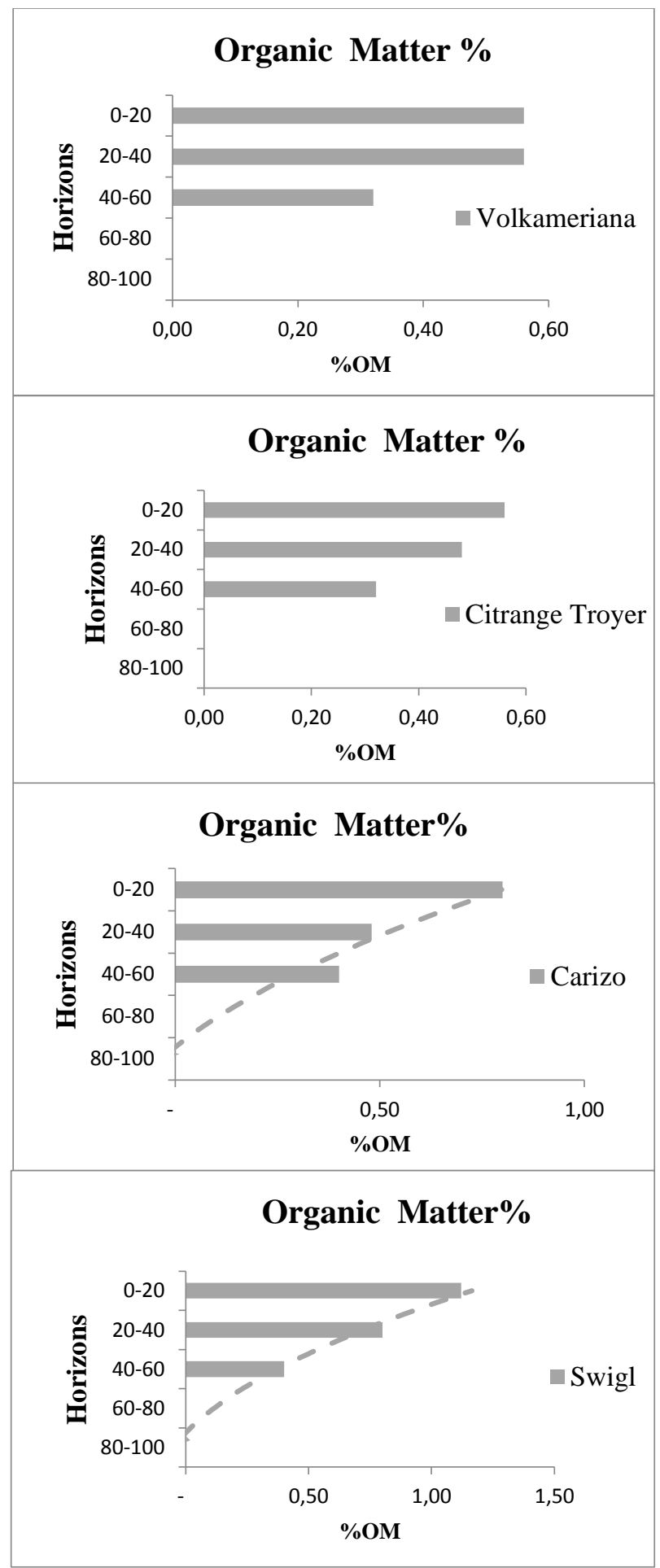




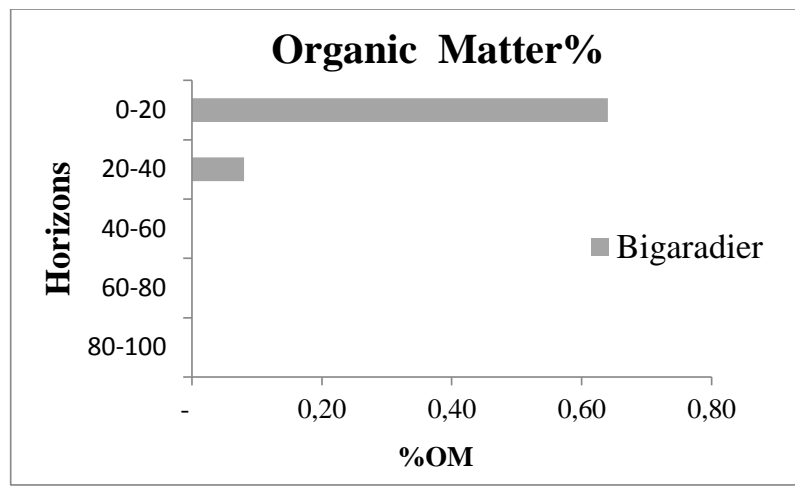

Fig.3. Variation of organic matter (\%) at different rootstocks with depth

A decrease in electrical conductivity versus depth at different rootstocks mainly related to the localized irrigation method adopted at the study site, which is characterized by localized water supply and the frequent used of the flow reduced at low pressures. Also the absence of precipitation and irrigation and high evapotranspiration, may cause the accumulation of salts at the surface layer. This mode reduces relatively pollution of the aquifer by infiltration of dissolved salts. (Fig.4).
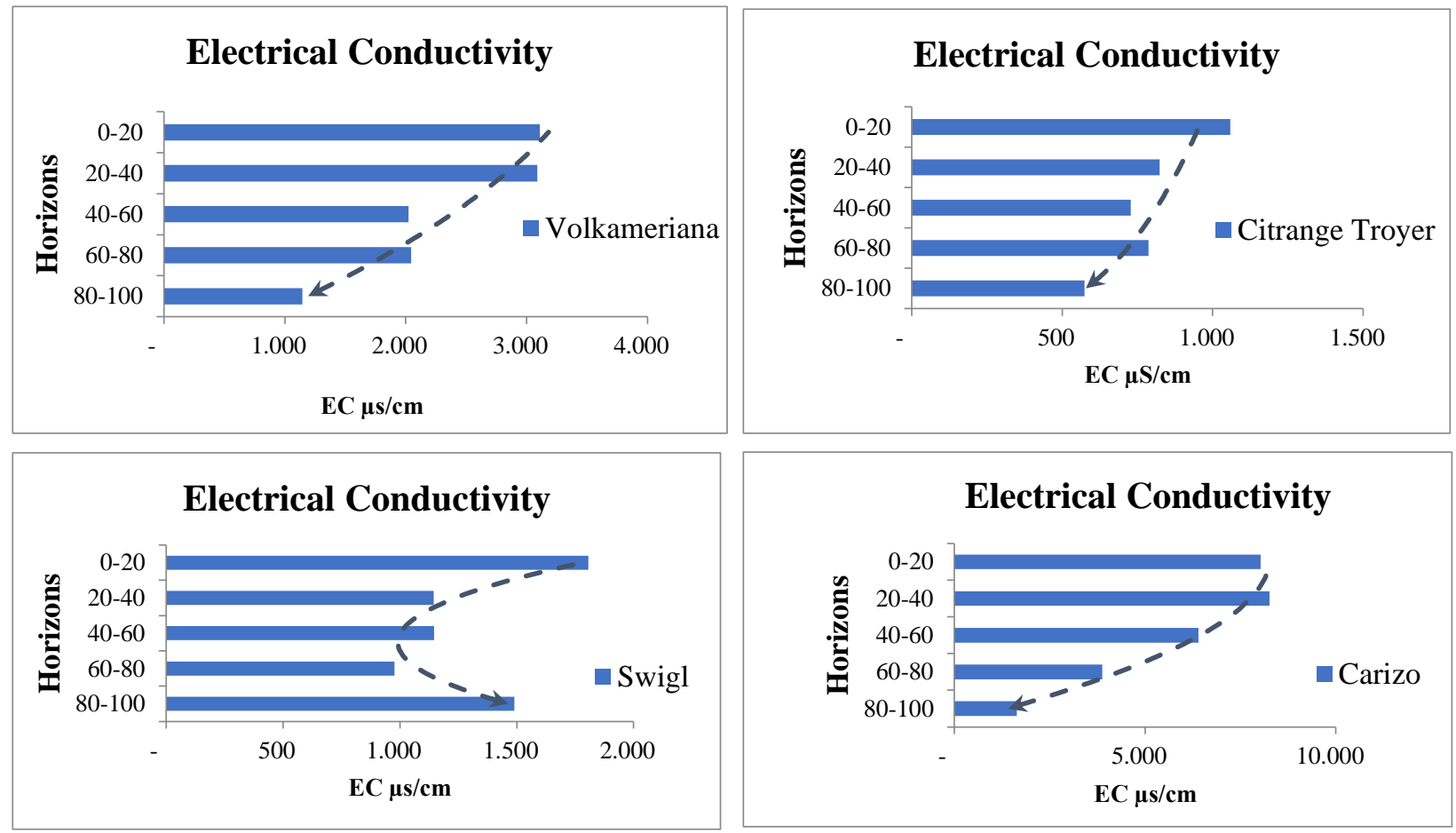


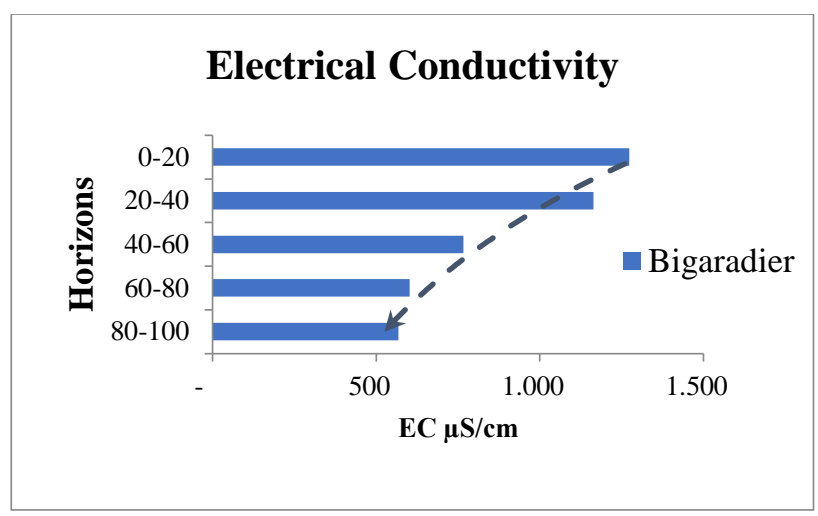

Fig.4. Variation of electrical conductivity $(\mu \mathrm{S} / \mathrm{cm})$ at different rootstocks with depth.

The concentrations of orthophosphate in different horizons and from different rootstocks show a considerable drop with depth.This can be explained by the fact that the fertilizer phosphore made at the site remains at the surface layers away from roots deep nutrition. According to (Huguet, 1978), whatever the nature of the soil, phosphorus is a little movable element and migrates deep in very small quantities. (Fig. 5).
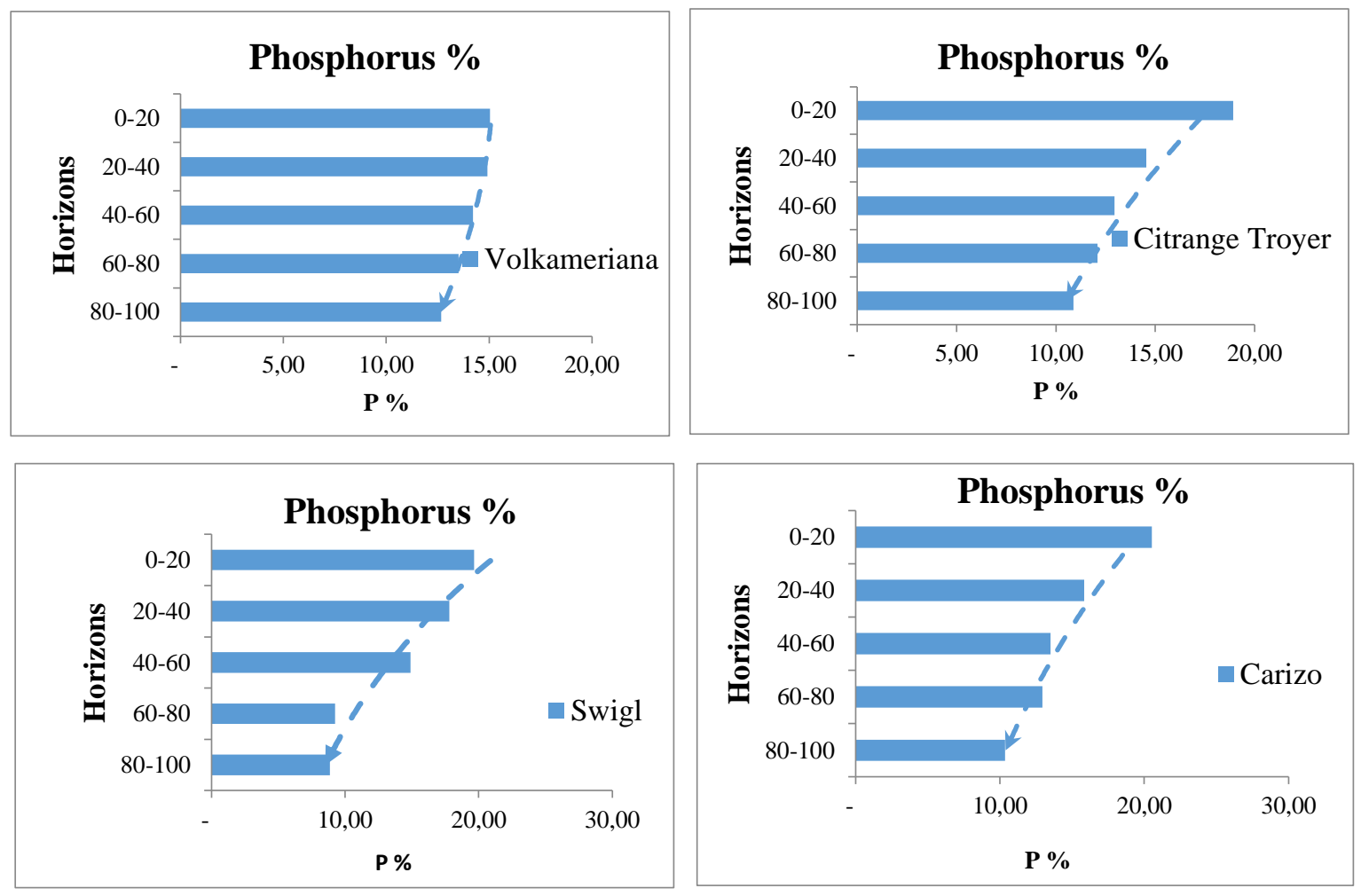


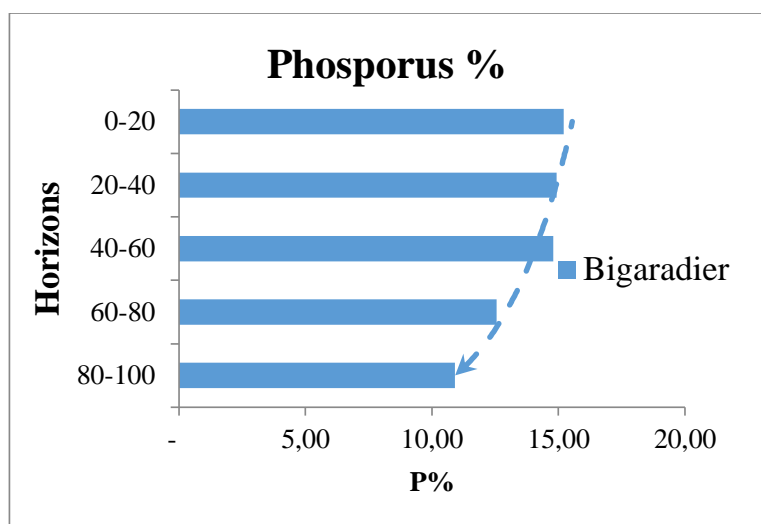

Fig.5. Variation of phosphorus (\%) at different rootstocks with depth.

Nitrates are very soluble in the water, therefore very mobile. They just have to be in excess in comparison with the needs of plants so that they are leached into the groundwater (Le Clech, 1995).The irrigation mode can act directly on the draining of waters and cause the percolation of large amounts of nitrates in depth. For drip irrigation, a loss of nitrate leaching is relatively unimportant. According to our results, the distribution of nitrates with depth shows a decrease in concentrations. This can be explained by a decrease in mineralization with depth that is quite logical given the decrease in organic matter content in the lower layers. These are related to the decrease the biodegradability of nitrates compounds due to involvement of the aminonitrates in more complex forms (Soudi et al, 1990). (Fig.6).
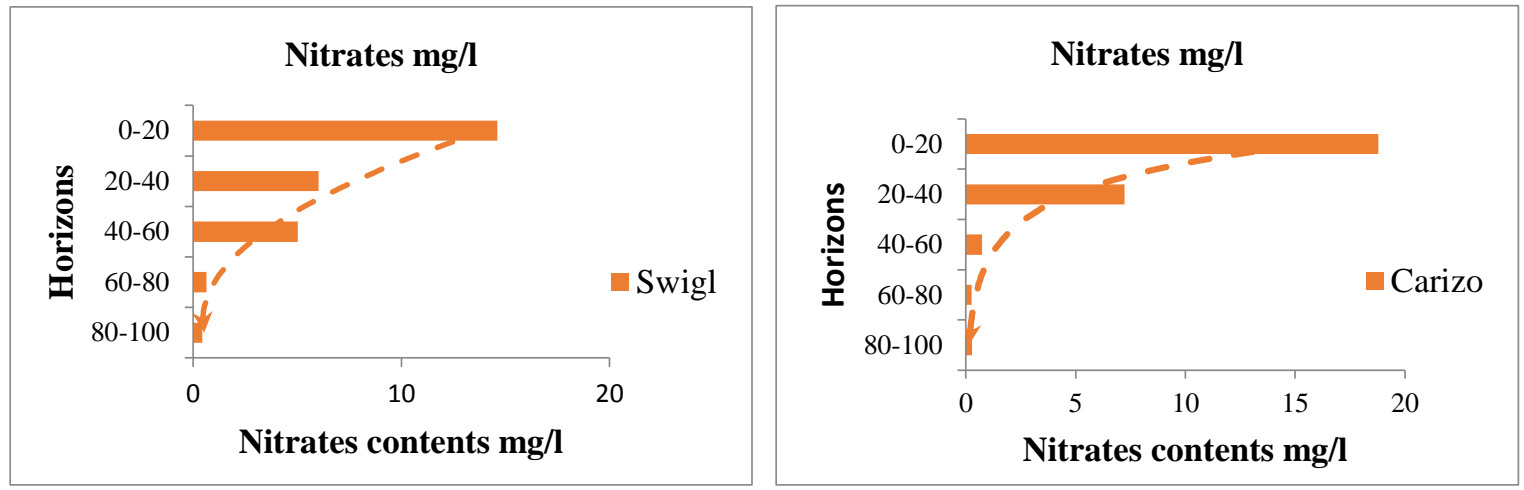

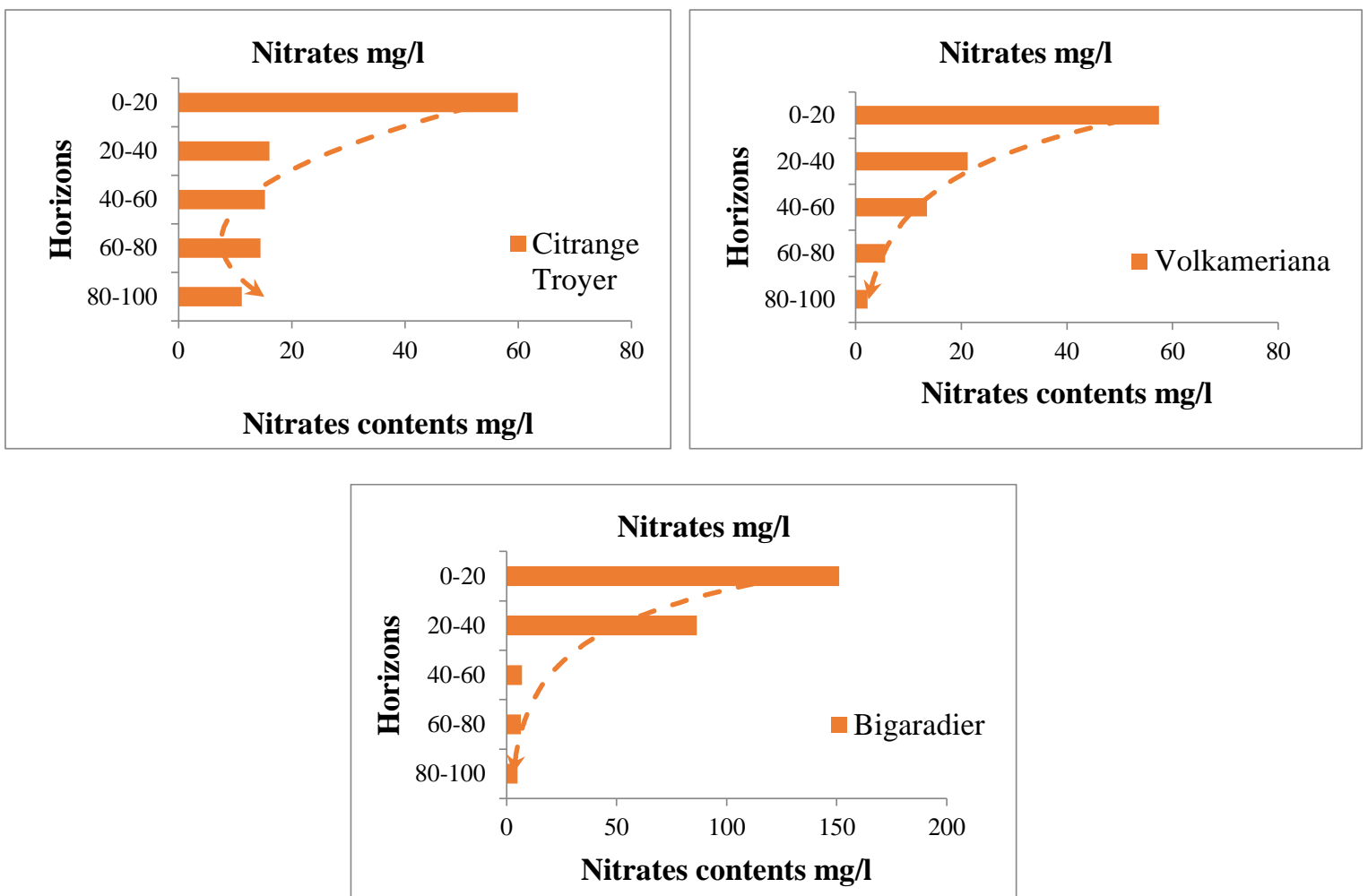

Fig.6. Variation of nitrates $(\mathrm{mg} / \mathrm{l})$ at different rootstocks with depth.

The vertical distribution of the percentage of calcium carbonate shows an increase of contents according to the depth, and under different rootstocks, this is mainly due to the percolation of water draining limestone to the depth (Fig.7). Similar studies have shown that soils with high concentrations of carbonates have very high $\mathrm{pH}$ values (Wenming et al, 2001; Moral et al, 2002; Jalali and Khanlari, 2008; Sayyad et al, 2010).
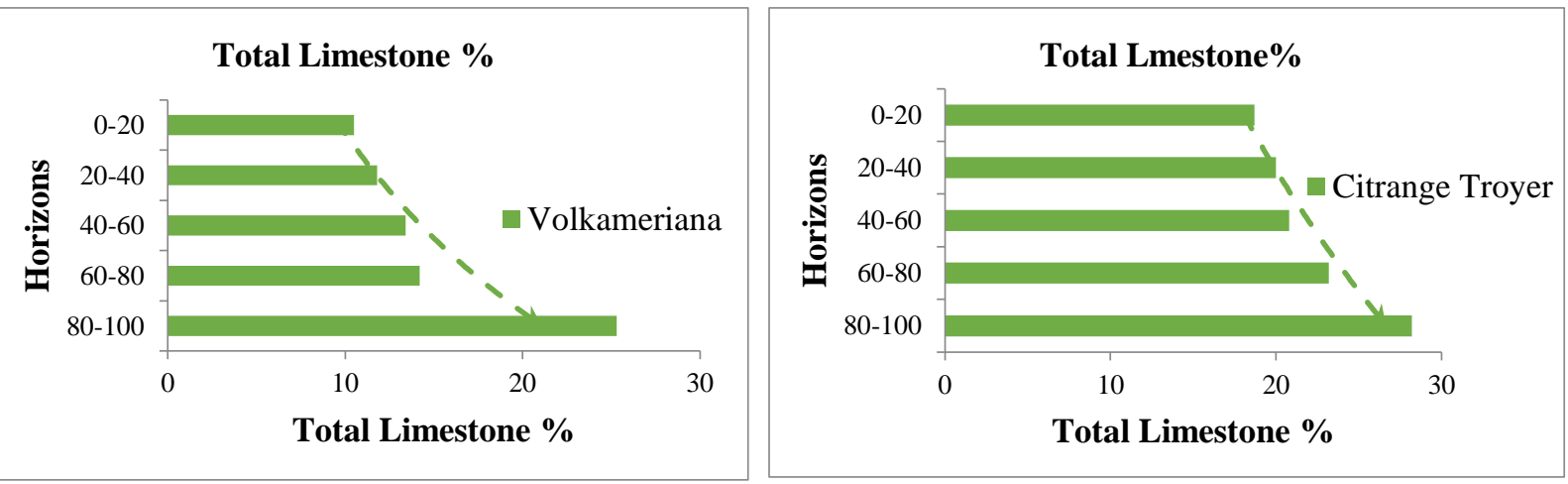

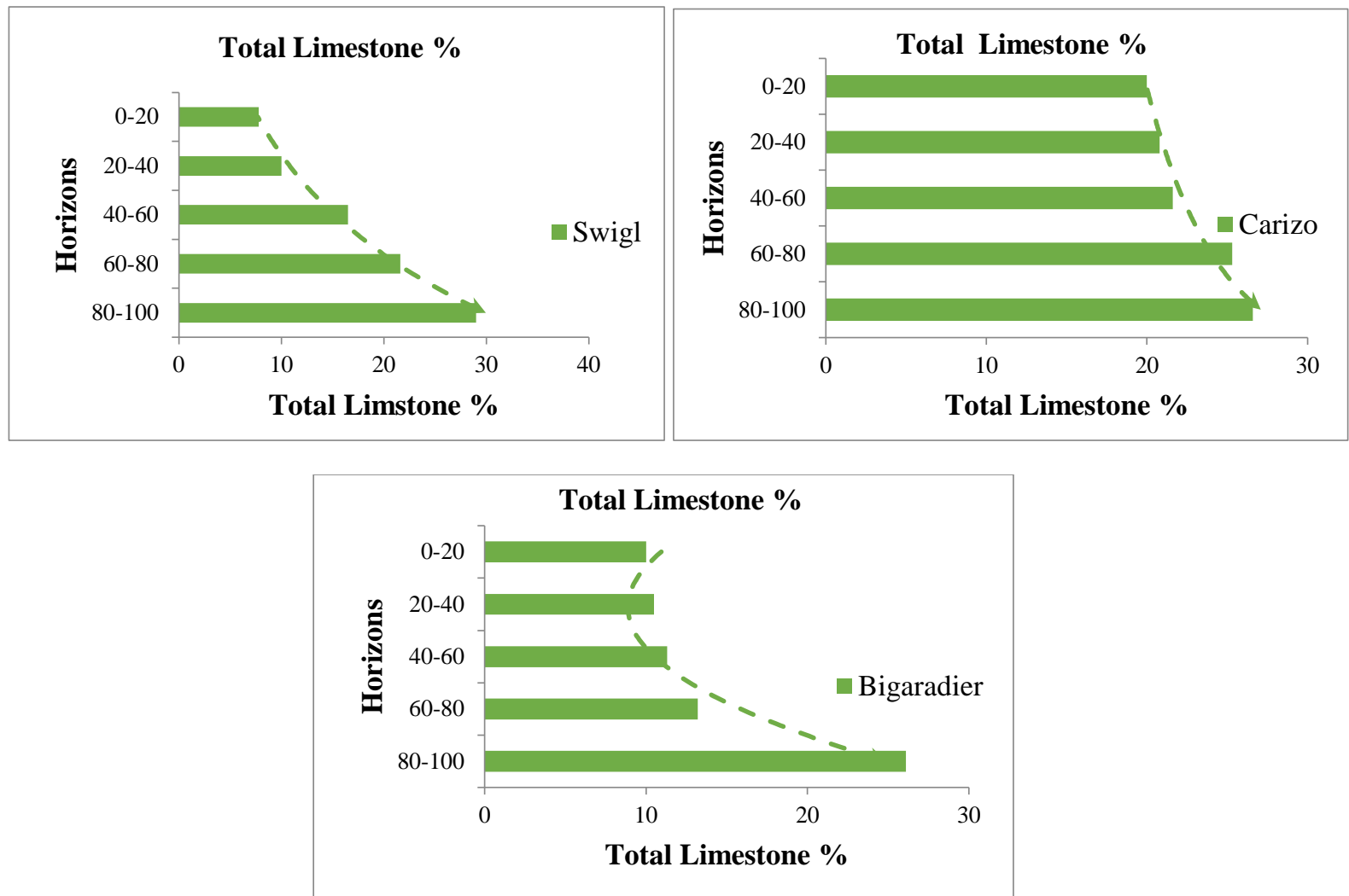

Fig.7. Variation of total limestone (\%) at different rootstocks with depth.

This causes an increase in $\mathrm{pH}$, the dissolution of limestone under the effect of irrigation and contributes to the enrichment of the soil in ion calcium. Indeed, this last dissolves in the soil solution, takes the place with protons, which consequently increases the soil $\mathrm{pH}$, which tends toward alkalinity. This phenomenon is much more accentuated by the use of a calcareous amendments and fertilization based combined calcium ion in an anion of nutritious elements example of calcium nitrate used as a fertilizer at the farm (Pernes et al, 2002) (Fig.8).
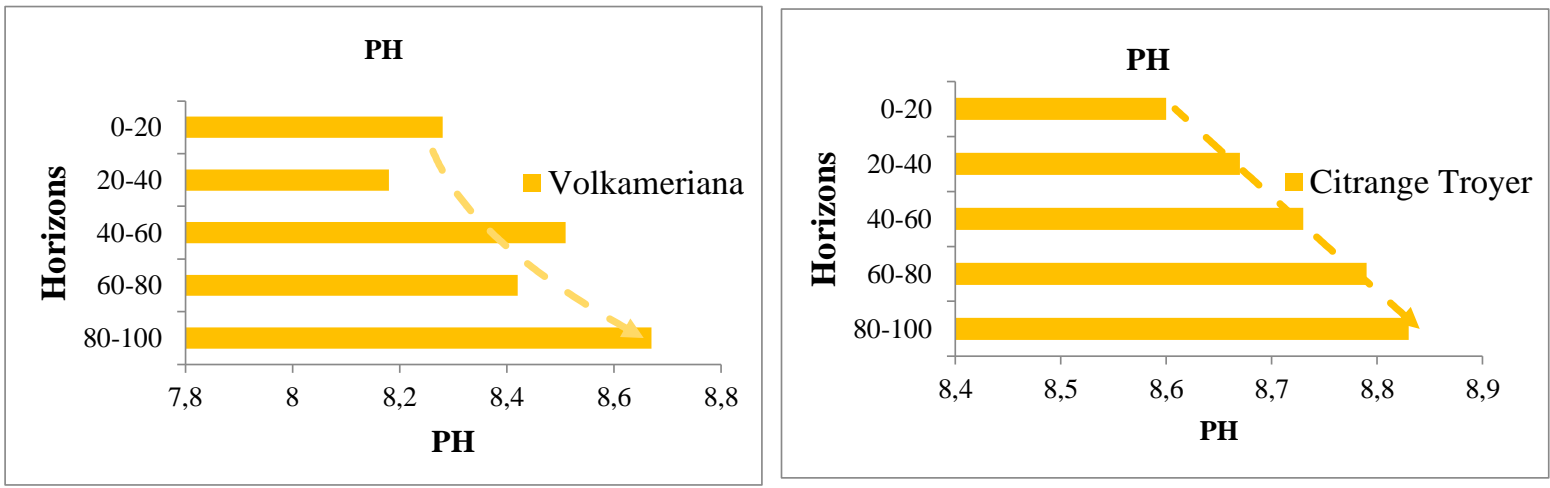

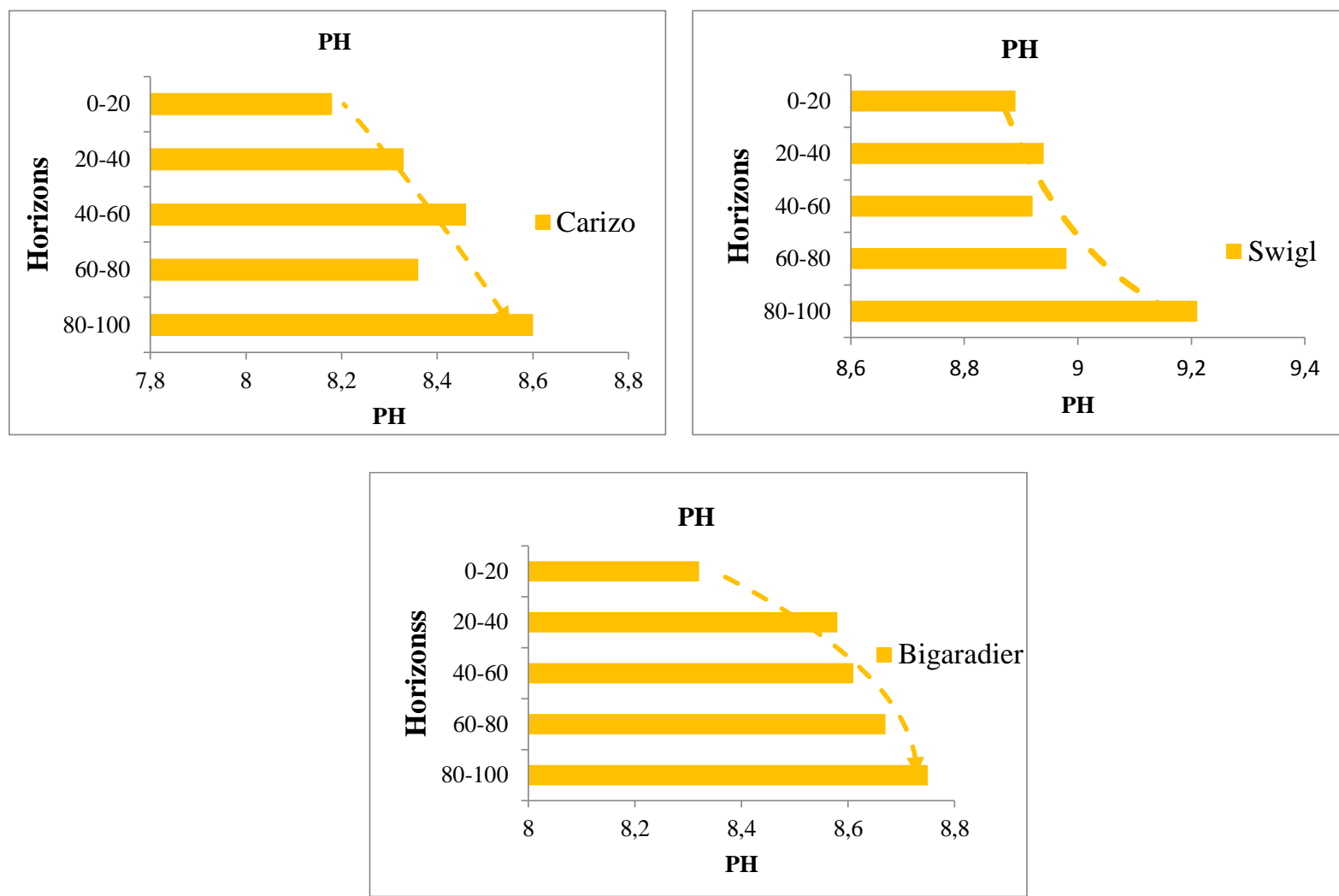

Fig.8. Variation of $\mathrm{pH}$ at different rootstocks with depth.

The important parameter for assessing the soil risk sodisation is the ESP (exchangeable sodium percentage). From the obtained results, $75 \%$ of samples have ESP $10,93=<15 \%$, so the risk of alkalinization is low. Exchangeable sodium content greater than $15 \%$ indicates that the soil contains too much sodium that is manifested by the reduction of the porosity of the soil; this limits the circulation of water and air in the soil. This will cause water stress while irrigating since water does not reach the roots.

\section{Statistical study of soil quality}

For analyzing the physico-chemical parameters of soil, individuals are the five soils sample under different horizons and rootstocks. The variables are: the electrical conductivity $1 / 5, \mathrm{pH}$, organic matter, Calcium carbonate, phosphorus, and the nitrate content.

Table 1 shows the variances expressed for each factor and their totals. These factorial axes selected for this statistical analysis, are representative of the data set variance.

Tables 2 to 6 show the different correlation relationships between the various parameters in each level of rootstock. 
Table 1. Eigenvalues and percentages of variance associated with each component.

\begin{tabular}{|l|l|l|l|l|l|}
\hline $\begin{array}{l}\text { Profiles } \\
\text { « rootstocks" }\end{array}$ & Eigenvalues & $\begin{array}{l}\text { F1 } \\
(\% \text { Total } \\
\text { variance } \\
\text { expressed })\end{array}$ & Eigenvalues & $\begin{array}{l}\text { F2 } \\
(\% \text { Total } \\
\text { variance } \\
\text { expressed })\end{array}$ & $\begin{array}{l}\text { \% } \\
\text { Cumulative } \\
\text { variance }\end{array}$ \\
\hline R.CARIZO & 5,25 & 87,58 & 0,48 & 8,13 & 95,722 \\
\hline R.SWIGL & 4,63 & 77,22 & 1,19 & 19,88 & 97,107 \\
\hline R.BIGARADIER & 4,07 & 67,869 & 1,23 & 20,42 & 88,444 \\
\hline R.VOLKAMERIANA & 4,65 & 77,58 & 0,75 & 12,62 & 90,205 \\
\hline $\begin{array}{l}\text { R.CITRANGE } \\
\text { TROYER }\end{array}$ & 4,29 & 71,503 & 1,34 & 22,42 & 93,927 \\
\hline
\end{tabular}

Table 2. Correlation matrix between the physico-chemical parameters of the soil under the rootstocks Carizo.

\begin{tabular}{|c|c|c|c|c|c|c|}
\hline & $\mathbf{N O}_{\mathbf{3}^{-}}$ & $\mathbf{O M}$ & $\mathbf{P H}$ & $\mathbf{C C}$ & $\mathbf{P}$ & $\mathbf{E C}$ \\
\hline $\mathbf{N O}_{3}{ }^{-}$ & 1 & & & & & \\
\hline $\mathbf{O M}$ & $\mathbf{0 , 8 8 0}$ & 1 & & & & \\
\hline $\mathbf{P H}$ & $-0,833$ & $-0,760$ & $\mathbf{1}$ & & & \\
\hline $\mathbf{C C}$ & $-0,727$ & $\mathbf{- 0 , 9 5 1}$ & $\mathbf{0 , 7 4 1}$ & 1 & & \\
\hline $\mathbf{P}$ & $\mathbf{0 , 9 5 3}$ & $\mathbf{0 , 9 2 7}$ & $-0,935$ & $-0,853$ & 1 & \\
\hline $\mathbf{E C}$ & $\mathbf{0 , 6 9 0}$ & $-0,786$ & $-0,786$ & $\mathbf{- 0 , 9 8 0}$ & 0,839 & 1 \\
\hline
\end{tabular}

$\mathrm{NO}_{3}{ }^{-}$: Nitrates; OM: Organic Matter; PH: Hydrogen potential; TL: Total Limestone; P: Phosphorus; EC: Electrical Conductivity.

Table 3. Correlation matrix between the physico-chemical parameters of the soil under the rootstocks Swigl.

\begin{tabular}{|c|c|c|c|c|c|c|}
\hline & $\mathbf{N O}_{\mathbf{3}^{-}}$ & $\mathbf{O M}$ & $\mathbf{P H}$ & $\mathbf{C C}$ & $\mathbf{P}$ & $\mathbf{E C}$ \\
\hline $\mathbf{N O}^{-}$ & 1 & & & & & \\
\hline $\mathbf{O M}$ & $\mathbf{0 , 9 4 7}$ & 1 & & & & \\
\hline $\mathbf{P H}$ & $-0,666$ & $-0,691$ & 1 & & & \\
\hline $\mathbf{C C}$ & $-0,855$ & $\mathbf{- 0 , 9 3 9}$ & $\mathbf{0 , 8 7 8}$ & 1 & & \\
\hline $\mathbf{P}$ & $\mathbf{0 , 9 0 5}$ & $\mathbf{0 , 9 8 1}$ & $-0,756$ & $\mathbf{- 0 , 9 5 9}$ & 1 & \\
\hline $\mathbf{E C}$ & $\mathbf{0 , 6 8 2}$ & 0,535 & 0,075 & $-0,236$ & 0,412 & 1 \\
\hline
\end{tabular}

$\mathrm{NO}_{3}{ }^{-}$: Nitrates; OM: Organic Matter; PH: Hydrogen potential; CC: Calcium carbonate; P: Phosphorus; EC: Electrical Conductivity.

Table 4. Correlation matrix between the physico-chemical parameters of the soil under the rootstocks Volkameriana.

\begin{tabular}{|c|c|c|c|c|c|c|}
\hline & $\mathbf{N O}_{\mathbf{3}^{-}}$ & $\mathbf{O M}$ & $\mathbf{P H}$ & $\mathbf{C C}$ & $\mathbf{P}$ & $\mathbf{E C}$ \\
\hline $\mathbf{N O}_{\mathbf{3}^{-}}$ & 1 & & & & & \\
\hline $\mathbf{O M}$ & $\mathbf{0 , 7 8 6}$ & 1 & & & & \\
\hline $\mathbf{P H}$ & $-0,620$ & $-0,800$ & 1 & & & \\
\hline $\mathbf{C C}$ & $-0,635$ & $-0,736$ & $\mathbf{0 , 8 4 4}$ & 1 & & \\
\hline $\mathbf{P}$ & $-0,506$ & $-0,743$ & 0,689 & 0,270 & 1 & \\
\hline $\mathbf{E C}$ & $\mathbf{0 , 7 7 8}$ & $\mathbf{0 , 8 9 4}$ & $\mathbf{- 0 , 9 6 9}$ & $\mathbf{- 0 , 8 8 8}$ & $-0,668$ & 1 \\
\hline
\end{tabular}

$\mathrm{NO}_{3}{ }^{-}$: Nitrates; OM: Organic Matter; PH: Hydrogen potential; CC: Calcium carbonate; P:

Phosphorus; EC: Electrical Conductivity 
Table 5.Correlation matrix between the physico-chemical parameters of the soil under the rootstocks Citrange troyer.

\begin{tabular}{|c|c|c|c|c|c|c|}
\hline & $\mathbf{N O}_{\mathbf{3}^{-}}$ & $\mathbf{O M}$ & $\mathbf{P H}$ & $\mathbf{C C}$ & $\mathbf{P}$ & $\mathbf{E C}$ \\
\hline $\mathbf{N O}_{3}{ }^{-}$ & 1 & & & & & \\
\hline $\mathbf{O M}$ & $\mathbf{0 , 6 6 5}$ & 1 & & & & \\
\hline $\mathbf{P H}$ & $-0,803$ & $\mathbf{- 0 , 9 6 5}$ & 1 & & & \\
\hline $\mathbf{C C}$ & $-0,594$ & $-0,873$ & $\mathbf{0 , 9 0 4}$ & 1 & & \\
\hline $\mathbf{P}$ & 0,395 & $-0,023$ & $-0,027$ & 0,397 & 1 & \\
\hline $\mathbf{E C}$ & $\mathbf{0 , 8 8 2}$ & $\mathbf{0 , 7 6 3}$ & $\mathbf{- 0 , 9 0 5}$ & $-0,846$ & 0,034 & 1 \\
\hline
\end{tabular}

$\mathrm{NO}_{3}{ }^{-}$: Nitrates; OM: Organic Matter; PH: Hydrogen potential; CC: Calcium carbonate; P: Phosphorus; EC: Electrical Conductivity

Table 6. Correlation matrix between the physico-chemical parameters of the soil under the rootstocks Bigaradier.

\begin{tabular}{|c|c|c|c|c|c|c|}
\hline & $\mathbf{N O}_{\mathbf{3}^{-}}$ & $\mathbf{O M}$ & $\mathbf{P H}$ & $\mathbf{C C}$ & $\mathbf{P}$ & $\mathbf{E C}$ \\
\hline $\mathbf{N O}_{\mathbf{3}} \mathbf{O M}^{-}$ & 1 & & & & & \\
\hline $\mathbf{P H}$ & $-0,691$ & $\mathbf{- 0 , 9 3 0}$ & 1 & & & \\
\hline $\mathbf{C C}$ & $-0,581$ & $-0,774$ & $\mathbf{0 , 5 0 2}$ & 1 & & \\
\hline $\mathbf{P}$ & $-0,285$ & 0,364 & $-0,275$ & $-0,248$ & 1 & \\
\hline $\mathbf{E C}$ & $\mathbf{0 , 8 0 6}$ & $\mathbf{0 , 9 0 9}$ & $-0,755$ & $-0,802$ & 0,312 & 1 \\
\hline
\end{tabular}

$\mathrm{NO}_{3}{ }^{-}$: Nitrates; OM: Organic Matter; PH: Hydrogen potential; CC: Calcium carbonate; P: Phosphorus; EC: Electrical Conductivity

There is a positive correlation between the organic matter, nitrates, and the electric conductivity in relation to a process of mineralization. Stated differently, the more the organic matter content, the higher the concentration of nitrates, the electrical conductivity increase too.

Likewise, the higher the percentage of limestone increase the higher the $\mathrm{pH}$ increases. This is related to the dissolution of limestone as a result of irrigation, thus contributing to the soil enrichment in calcium ions; the calcium dissolved in the soil solution, is substituted with protons, which consequently increases the soil $\mathrm{pH}$, which tends toward alkalinity. A negative correlation exists between the organic matter and $\mathrm{pH}$, the basicity of $\mathrm{pH}$ interposes the development of flora responsible of ground mineralization.

The projection of individuals according to F1 and F2 axis (Fig.9), allowed distinguishing 3 groups: The $1^{\text {st }}$ group includes $0-20$ and $20-40$ horizons: Horizons rich in dissolved salts, nitrates and organic matter. The $2^{\text {nd }}$ intermediate group is the 40-60 horizons (limit of the root zone) and the $3^{\text {rd }}$ group corresponds to 60-80 and 80-100 backgrounds: rich in limestone horizons and has a high $\mathrm{pH}$. 

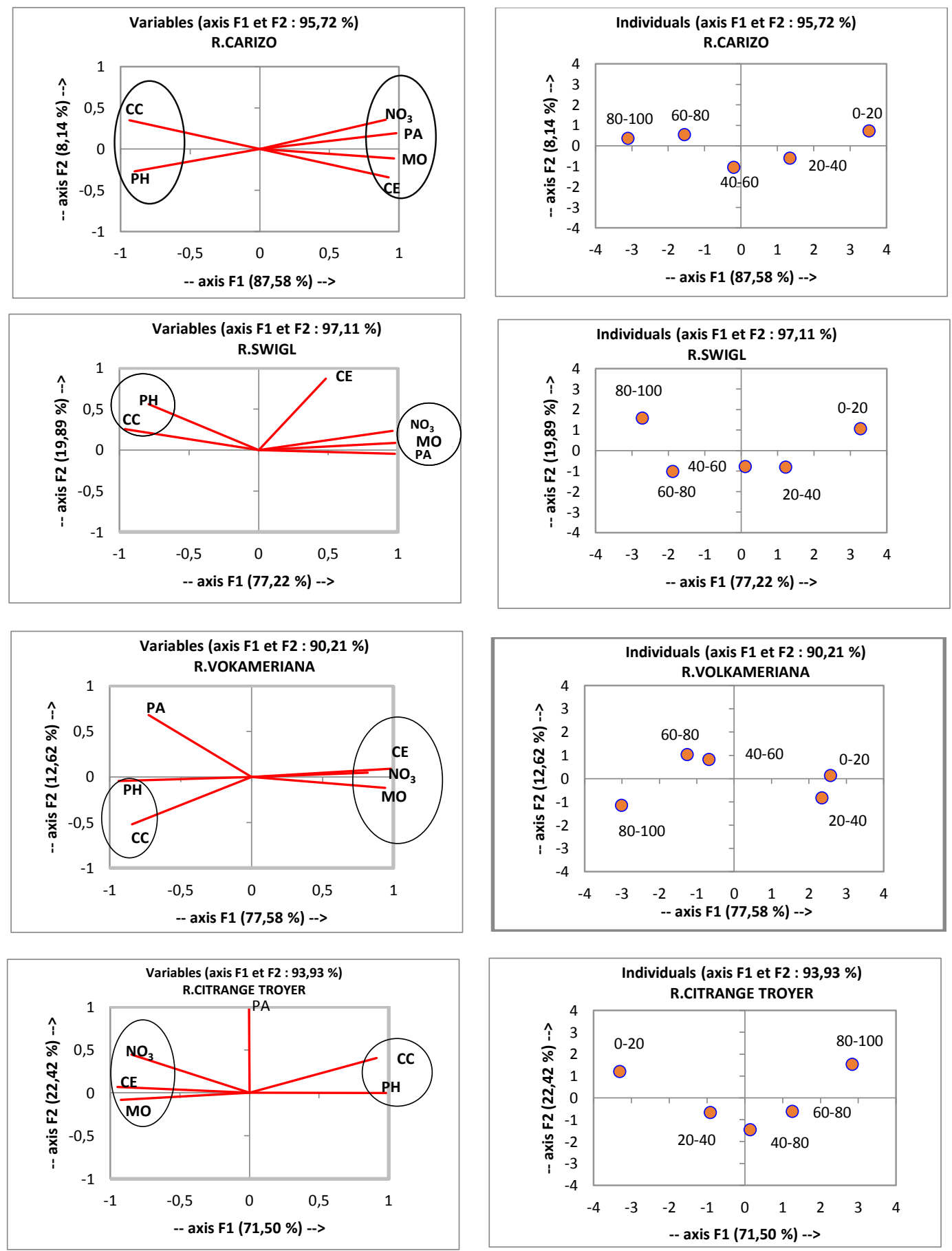

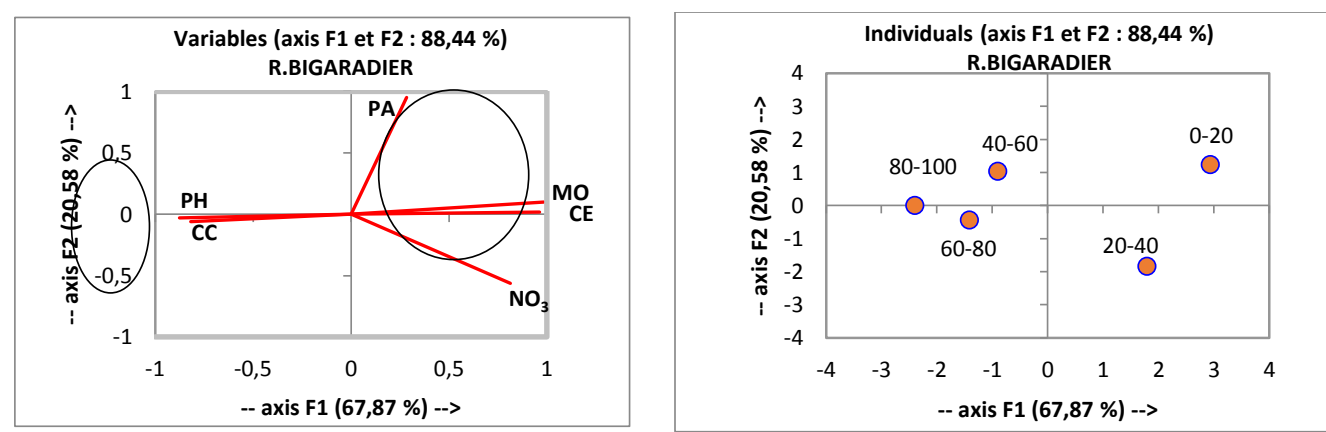

Fig. 9: Projection of variables and representation of the factorial plane horizons on F1 and F2.

\section{Summary and Conclusion}

Agricultural intensification in irrigated areas is responsible for diffuse pollution and deterioration of the quality of soil .The present study diagnosed the current state of the horizontal and vertical soil quality for citrus orchard at the Agafay farm, based primarily on the analysis of physical and chemical quality parameters, their variations under different horizons and from different rootstocks.

The results revealed that the state of the soil quality is not very alarming. The soil has a light texture characterized by the dominance of the sand fraction, the $\mathrm{pH}$ has an alkaline trend, relatively low levels of organic matter and the soil electrical conductivity shows that the soil is saline. By contrast, the nitrate levels appeared more concentrated in the variety of orange (Navel lane late). This is attributed to a higher supply of nitrates fertilizers.

The vertical distribution of the various chemical elements in different horizons and under different rootstocks showed that the type of rootstock has no effect on the chemical composition. Indeed, the same patterns of evolution under different rootstocks are found: lower salinity levels, nitrates, organic matter, and phosphorus, rather than the percentage of limestone and $\mathrm{pH}$. The localized irrigation system adopted at the study site led to minimizing losses of nutritive elements applied on the surface by leaching and consequently a reduction of pollution of the groundwater.

The study site reflects the case of a perfect site where agricultural practices are well mastered. The results obtained allowed drawing a low limit of pollution, beyond it nothing can deviate to the adverse bounds, and everything is in order and using a better management.

The setting up of a soil quality surveillance system in irrigated areas is needed imperatively and remains an important management tool for the conservation and sustainability of the production system. 


\section{References:}

1. ABHT: Agence Hydraulique du Bassin de Tensift, (1987). Etude du plan directeur intégré d'aménagement des eaux du bassin du Tensift. Octobre 1987.64p.

2. AFES. (1992). Référentiel pédologique 1992: Principaux sols d'Europe. INRA Paris. 222p.

3. AFNOR - ISO. (1992). Projet de norme ISO/CD/11259: Qualité du sol. Description des sols et des sites. Version n8 8 de février 1992.

4. Ambroggi, R., Thuille, G. (1952). Haouz de Marrakech, hydrogéologie du Maroc. Notes, Mém., Serv. Géol. Maroc, Nº97.

5. Badraoui, M., Soudi, B., Merzouk, A., Farhat, A., M'hamdi, A. (1998b). Changes of soil qualities under irrigation in the Bahira region of Morocco: Salinization. Advances in GeoEcology 31.

6. Baize. (1988). Guide des analyses courantes en pédologie : choix, expression, présentation et intérpretaion.INRA, Paris.

7. Baldock, J. A., Skjemstad, J. O. (2000). Role of the soil matrix and minerals in protecting natural organic materials against biological attack. Organic Geochemistry 31: 697-710. doi: 10.1016/S01466380(00)00049-8.

8. Bendra, B., Fetouani, S., Laffray, X., Vanclooster, M., Sbaa, M., Aleya, L. (2012). Effects of irrigation on soil physico-chemistry: a case study of the Triffa plain (Morocco). Irrigation and Drainage. DOI: 0.1002/ird.688.

9. Bensaadi, A. (2004). Contribution à l'étude de l'état nutritionnel des vergers de pommier dans la région d'Ychemoul., Thèse ing, Agro, Univ Batna., $88 \mathrm{P}$.

10. Berdai, H., Soudi, B., Bellouti, A. (2004). Contribution à l'étude de la pollution nitrique des eaux souterraines en zones irriguées : cas du Tadla. Revue H.T.E. N ${ }^{\circ} 128$ - Mars 2004.

11. Chouikri, I., El Mandour, A., El Jeffal, M., Casas, A., Manar, A. (2014). Les réservoirs du Haouz Occidental : Approche géologique, géophysique et hydrogéologique. 41st IAH International Congress "Groundwater: Challenges and Strategies» - Marrakech, September, 15-19, 2014.

12. Day, P.R. (1965). Particle fractionation and particle-size analysis. In C.A. Black et al (ed.) methods of soil analysis, Part 1.Agronomy 9:545-567. 
13. ofSoilAnalysis, Part1, Black CA (ed.). Agronomy9: 545-567.

14. Doran, J. W., Parkin, T B. (1994). Defining and assessing soil quality. In defining soil quality for a sustainable environment. Ed. J W Doran D C Coleman D F Bezdicek and B A Stewart pp. 3-21 Madison, WI SSSA Spec. Publ. 35.

15. EPA. (1994). Control tendency of hazardous waste materials in Taiwan.In: Proceedings of conference on Hazard Waste Treatment Technology. Environnemental Protection Agency (EPA), Taiwan ROC, pp. 1-27

16. FAO. (2003). Les engrais et leurs applications, Précis à l'usage des agents de vulgarisation agricole. Quatrième édition, Editions F.A.O., I.F.A. (Paris, France) et IMPHOS (Casablanca, Maroc). 84 P.

17. Farhat, A. (1995). Effets de l'irrigation par pivot sur la qualité des sols dans la Bahira: situation actuelle et perspectives de développement. Thèse de 3ème cycle, IAV Hassan II, Département Sci. Sol, Rabat, Maroc.

18. Fetouani, S., Sbaa, M., Vanclooster, M., Bendra, B. (2008). Assessing groundwater quality in the irrigated plain of Triffa (North-East Morocco). Journal of Agricultural Water Management, 95, 133-142. doi:10.1016/j.agwat.2007.09.009.

19. Fetouani, S., Bendra, B., Vanclooster, M., Sbaa, M. (2013). Physicochemical assessment of agricultural pollution on groundwater and soil quality in an agricultural farm (North eastern morocco). International Journal of Engineering Science and Technology (IJEST), Vol. 5 No.11 Nov 2013.

20. Gagnard, J., Huguet, J., Ryser, J. P. (1988). L'analyse du sol et du végétal dans la conduite de la fertilisation, le contrôle de la qualité des fruits. Secrétariat générale OILB/SROP, Edition - Diffusion ACTA., $87 \mathrm{P}$.

21. Heller, A., Feldman, J., Say, Vreeke. M. S., Tomasco, M. F. (1998). Small volume in vitro analyte sensor. PCT Int. Appl.WO9835225 A1 (US Pat. Appl. WO -US2652).

22. Huguet, J. (1978). Pratique de la fertilisation minérale des arbres fruitiers. Ed. INVUFLEC. 43p. 
23. Jalali, M., Khanlari, Z. V. (2008). Environmental contamination of Zn, $\mathrm{Cd}, \mathrm{Ni}, \mathrm{Cu}$, and $\mathrm{Pb}$ from industrial areas in Hamadan Province, western Iran Environmental Geology, vol. 55, $\mathrm{n}^{\circ}$ 7, pp. 1537-1543

24. Joret, G., Hebert, J. (1955). Contribution à la détermination du besoin des sols en acide phosphorique. Annals of Agronomy 2: 233-299.

25. Larson, W.E., Pierce, F.J. (1991). Conservation and enhancement of soil quality. In Evaluation for Sustainable Land Management in the Developing World. Vol. 2: Technical Papers.

26. Le Clech, B. (1995). Environnement et agriculture. Synthèse Agricole 1995. 290 pp.

27. Mathieu, C., Ruellan, A. (1980). Evolution morphologique des sols irrigués en région méditerranéenne semi aride. Cahier ORSTOM, série pédo. 13; 3-25.

28. Nelson, D. W., Sommer, L. E. (1982). Total carbon, organic carbon, and organic matter. p. 539-579. In A.L. Page (ed.) Methods of Soil Analysis. 2nd Ed. ASA Monogr. 9(2). Amer. Soc. Agron. Madison, WI.

29. Moral, R., Cortés, A., Gomez, I., Mataix-Beneyto, J. (2002). Assessing changes in $\mathrm{Cd}$ phytoavailability to tomato in amended calcareous soils. Bioresource Technology, vol. 85, $\mathrm{n}^{\circ}$ 1, pp. 63-68.

30. Olsen, SR., Cole, C. V., Watanabe, F S. (1954). Estimation of Available Phosphorus in Soils by Extraction with Sodium Bicarbonate.US Department of Agriculture, Circular 939: 67-96.

31. Mathieu, C., Pieltain, F. (2003). Analyse chimique des sols. Ed. Tec et doc. Lavoisier, Paris, 292 p.

32. Pernes, A., Tessier, D. (2002). Influence du pH sur les propriétés des sols : l'essai de longue durée des 42 plot les à Versailles Revue des sciences de l'eau / Journal of Water Science, vol. 15, p. 27-39.

33. Rahoui, M., Soudi, B., El Hadani, D., Benzakour, M. (1999 b). Evaluation de l'indice de la qualité des sols en zones irriguées: Cas des Doukkala. Géo Observateur 10: 103-113, décembre 1999.

34. Rahoui, M., Soudi, B., F, Id. Ahmad. (2002). Situation actuelle de la pollution nitrique des eaux souterraines dans le périmètre irrigué des Doukkala. Revue HTE N¹23 • Juin 2002.

35. Robert, M. (1992). Le sol, une ressource naturelle à préserver pour la production et 1'environnement. Cahier Agriculture, 1: 20-34. 
36. Sbai, A. (2006). Définition d'un réseau de suivi de la qualité des eaux souterraines dans le périmètre du n'fis (region de Marrakech).Revue HTE N ${ }^{\circ} 133 \cdot$ Mars - Juin 2006.

37. Sayyad, G., Afyuni, M., Mousavi, S. F., Abbaspour, K. C., Richards, B. K., Schulin, R. (2010).Transport of $\mathrm{Cd}, \mathrm{Cu}, \mathrm{Pb}$ and $\mathrm{Zn}$ in a calcareous soil under wheat and safflower cultivation- A column study. Geoderma 2010, vol. 154 pp. 311-320.

38. Soudi, B., Chiang, C. N., Zeraouli, M. (1990). Variations saisonnières de l'azote minéral et effet combiné de la température et de l'humidité du sol sur la minéralisation. Actes Inst. Agron. Vét. (Maroc) Vol 10 (1).pp: 29-38.

39. Umali, D. L. (1993). Irrigation-induced salinity. A growing problem for development and the environment. World Bank technical paper 215, p.78.

40. Wenming, D., Zhijun, G., Jinzhou, D., Liying, Z., Zuyi, T. (2001). Sorption characteristics of zinc (II) by calcareous soil - radiotracer study. Applied Radiation and Isotopes, vol. 54 pp. 371-375. 